\title{
Are Our Surgical Indications Accurate for Gallbladder Polyps?
}

\author{
(1) Ecem Memişoğlu, (1) Murat Alkan, (1) Ahmet Başkent
}

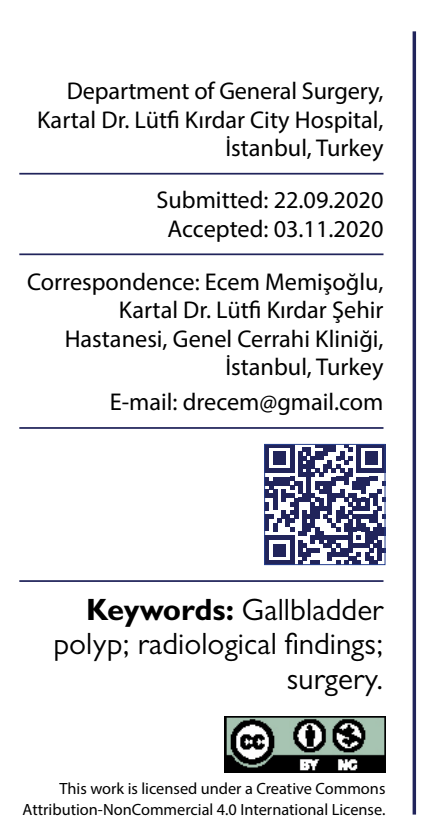

\section{ABSTRACT}

Objective: The gallbladder polyp (GBP)s are mostly known as non-neoplastic lesions and have malignancy potential, which is an essential factor in the follow-up and treatment of the patient. This study aimed to evaluate the indications for surgery and compare the radiological and pathological findings of patients who were operated with the pre-diagnosis of GBP.

Methods: The demographic and clinical data, histopathological features, interventions and complication rate of the patients who underwent surgery for GBP between January 2015 and June 2020 in our clinic were retrospectively evaluated in this study.

Results: Cholecystectomy was performed in 93 patients with a diagnosis of GBP. Multiple GBPs were observed in 44 (47.3\%) patients on radiological imaging, and the mean diameter of the polyps was $6 \mathrm{~mm}$. Polyps were found in 33 (35.5\%) of the 93 patients in histopathological examination. Cholesterolosis was detected in 29 (31.2\%) of the patients, cholelithiasis in $22(23.6 \%)$ patients, and no abnormality was found in $16(17.2 \%)$ patients. While cholesterolosis and cholelithiasis were seen together in II (I I.8\%) patients, cholelithiasis and GBP were detected in only one patient.

Conclusion: Clinical examination and imaging findings, such as the size, appearance and the number of polyps, have a critical role in the indication of surgery for patients with GBPs. The risk factors and the clinical findings of the patients should be considered together for an accurate surgery decision.

\section{INTRODUCTION}

Gallbladder polyp (GBP)s, which are detected incidentally during an abdominal ultrasound or cholecystectomy specimens, are the lesions that are formed by the protrusion of the gallbladder mucosa towards the lumen. The incidence of GBPs varies between $0.3 \%$ and $12.3 \%$ in adults. ${ }^{[1]}$ GBPs are known as true and pseudo-polyps. True polyps, which account for $5 \%$ of the GBPs, are with malignant or malignancy potential, classified as adenoma and adenocarcinoma. ${ }^{[2]}$ On the other hand, cholesterolosis polyps, hyperplastic polyp, inflammatory polyp, and focal adenomyomas are classified as pseudo-polyps. ${ }^{[1]}$

Imaging methods have an essential role in the diagnosis and treatment of GBP. The most widely used radiological imaging in GBP diagnosis is ultrasonography (i.e., transabdominal, conventional, high-resolution, three-dimensional, contrast-enhanced and endoscopic). Regarding other imaging modalities, computed tomography (CT) can be used for gall bladder adenocarcinoma classification or differentiation of true polyps and pseudo-polyps. Besides, magnetic resonance imaging (MR) and positron emission tomography (PET) can be used to differentiate benign and malignant polyps. ${ }^{[3]}$
Radiological imaging methods should distinguish GBPs from gallstones, mud and mucosal folds to be a good determinant in the diagnosis and treatment. It should also be able to distinguish pseudo-polyps from true polyps and measure the polyp sizes accurately. The management of true GBPs with malignancy is cholecystectomy. On the other hand, neither follow up nor surgery is recommended for pseudo-polyps detected by ultrasonography. ${ }^{[4]}$ Surgery is indicated for GBPs with $>10 \mathrm{~mm}$ dimension in symptomatic patients with complaints, such as abdominal pain, nausea and jaundice irrespective of no underlying pathology, such as gallstones or gallbladder inflammation. ${ }^{[4]}$ Besides, cholecystectomy should be recommended to patients over the age of 50, with primary sclerosing cholangitis (PSC)s, Indian ethnicity and sessile polyps because of the increased risk of malignancy. ${ }^{[5-7]}$

In this study, we aimed to evaluate the presenting symptoms of the patients and to compare the radiological and pathological findings of patients who operated with the pre-diagnosis of GBPs.

\section{MATERIALS AND METHODS}

The present study was approved by the Kartal Dr. Lütfi 
Kurdar City Hospital Ethics Committee on August 26, 2020 (no: 2020/5/4/184/7). This study was conducted with retrospective data analysis of the patients who were operated between January 2015 and June 2020 with GBPs diagnosis in the general surgery department of a tertiary referral hospital. The data of the cases, such as age, gender, presenting symptoms, duration of complaints, medical history, co-morbidities, radiological findings (i.e., gallbladder stone, gallbladder inflammation, presence of GBP, number of polyps, and polyp size), final pathological findings, type of surgery (i.e., laparoscopic cholecystectomy or laparotomy cholecystectomy), and hospital stay were recorded.

\section{Statistical analysis}

Data analysis was performed with SPSS version 20.0 (SPSS Inc., Chicago, IL). All continuous data were presented as means. The categorical data were presented as numbers and percentages.

\section{RESULTS}

The demographic and clinical data of 93 patients are summarized in Table I. Sixty-two $(66.6 \%)$ of the patients were female, and 31 (33.3\%) were male. Of the 33 patients had polyps on histopathological examination, $22(66.6 \%)$ were female, and II (33.3\%) were male. The mean age was 5 I (range: 26-7I). The average time from the patients' admission to the hospital with the onset of complaints was around four months. The mean duration of hospital stay was I.I days.

Regarding the ultrasonographic findings, the mean polyp size was $6.9(1.5-28) \mathrm{mm}$. There were $40(43 \%)$ patients with a polyp size of $\leq 5 \mathrm{~mm}$. Twenty two $(55 \%)$ of these patients were single polyps, and $18(45 \%)$ had multiple polyps. The largest polyp size was observed in patients with multiple polyps. A single polyp was detected in 14 (4I.2\%) of the patients with polyp size between $5-9 \mathrm{~mm}$ and in $13(68.4 \%)$ of the patients with polyp size $\geq 10 \mathrm{~mm}$ (Table I).

Nineteen (20.4\%) patients underwent cholecystectomy because of a polyp size of $\geq 10 \mathrm{~mm}$ in radiological imaging, which was the most crucial factor in deciding surgery. Two of these patients had no symptoms, such as abdominal pain or distension. The other two patients, who were asymptomatic, were operated because one was 50 years old and had multiple polyps and the other was older than 50 years and had cholelithiasis with polyps. Although the majority of the patients ( 72 patients $(77.4 \%)$ ) had polyps $\leq 10 \mathrm{~mm}$, they were operated because they were symptomatic. Cholelithiasis was also present in 35 (48.6\%) of these patients. Ninety-two patients underwent laparoscopic cholecystectomy, while only one patient had cholecystectomy with laparotomy due to a history of recurrent umbilical hernia.

The histopathological data of this study population are summarized in Table 2. Malignancy was not detected in any patient. In the histopathological examination, GBP was found in 33 (35.5\%) patients. Among these patients, II (33.3\%)
Table I. The clinical and demographic data of the study population

$\mathrm{n}=93(\%)$

\begin{tabular}{lc}
\hline Gender & \\
Female & $62(66.6)$ \\
Male & $31(33.3)$ \\
Age (min-max) (years) & $50(17-72)$ \\
Presenting symptom & \\
Abdominal pain & $79(84.9)$ \\
Distension & $10(10.7)$ \\
None & $4(4.3)$ \\
Co-morbidity & \\
Diabetes Mellitus & $9(9.7)$ \\
Hepatitis C & $2(2.1)$ \\
Number of polyps & \\
Single & $49(52.7)$ \\
Multiple & $44(47.3)$ \\
Polyp size & \\
$\leq 5$ mm & $40(43)$ \\
$5-9$ mm & $34(36.6)$ \\
$\geq 10$ mm & $19(20.4)$ \\
\hline
\end{tabular}

Table 2. Results

\begin{tabular}{lc}
\hline Histopathology results & $\mathbf{n ~ ( \% )}$ \\
\hline Cholesterolosis & $29(3 \mathrm{I} .2)$ \\
Cholesterol-related polyp & $32(34.4)$ \\
Adenomyoma & $1(1.07)$ \\
Metaplasia & $7(7.5)$ \\
Villous hypertrophy & $\mathrm{I}(1.07)$ \\
Cholelithiasis & $22(23.6)$ \\
\hline
\end{tabular}

had a single polyp, while 22 (66.6\%) had multiple polyps.

Cholelithiasis was detected in ultrasonography in 26 (27.9\%) patients, whereas II (II.8\%) patients had the diagnosis after the pathological examination. Ten (10.7\%) patients had the GBP diagnosis both in the ultrasonographic and pathological examination. On histopathological examination, cholelithiasis was found with gallbladder polyp only in one patient.

\section{DISCUSSION}

In our study, most of the patients who were operated due to GBPs were female, and the main presenting symptom was abdominal pain. Gallbladder polyps that prolapse to the Hartman pouch or obstruct the cystic duct opening cause functional abdominal pain. Therefore, it is difficult to distinguish whether the pain is due to gallbladder pathology in patients presenting with upper abdominal pain and dyspeptic complaints..$^{[8]}$ In our patients, approximately half of the gallbladder polyps were $5 \mathrm{~mm}$ in diameter and were operated on due to being symptomatic. 
Ultrasonography has an important place in distinguishing gallbladder polyps from other gallbladder pathologies. Stones, mud attached to the gallbladder wall or mucosal folds can be confused with gallbladder polyps. ${ }^{[3]}$ French et al. ${ }^{[9]}$ conducted a study with 13278 patients, compared the histopathological examination of cholecystectomy specimens and ultrasonographic findings. It revealed that ultrasonography only $50 \%$ correctly identified the polyp. In our study, this rate was $35.5 \%$.

There are controversial data regarding the follow-up and treatment of gallbladder polyps. Current guidelines recommend cholecystectomy for $\geq 10 \mathrm{~mm}$ polyps since they have an increased risk of malignancy. On the other hand, the recommendations vary for polyps between $5-9 \mathrm{~mm}$ in size. ${ }^{[1]}$

Babu et al. ${ }^{[10]}$ reported the results of a systematic review consisting of 43 studies. In 20 studies of this review, 2347 polyps were evaluated considering the size and histopathological results. They concluded that 228 of 356 true polyps were malignant, and 29 malignant polyps were between 5-10 mm. Furthermore, they reported no malignancy in any polyps $\leq 5 \mathrm{~mm}$ in size. In another review consisting of the results of 21 studies by Bhatt et al. ${ }^{[5]}$ reported that there were a significant number of malignant polyps $\leq 10$ $\mathrm{mm}$ in size. Still, no malignant cases were observed when the size of the polyp was $\leq 4.15 \mathrm{~mm}$. In our study, malignancy was not observed in any patients; even the patients had $\geq 10 \mathrm{~mm}$ polyps.

In cases with $\leq 10 \mathrm{~mm}$ GBPs, the presence of malignancy prompted clinicians to investigate risk factors to predict preoperative malignancy potential. Kwon et al. ${ }^{[1]}$ reported that malignant polyps were mostly observed as single polyps. However, they only evaluated the patients with polyp size of $\geq 10 \mathrm{~mm}$.

Park et al. ${ }^{[12]}$ reported the results of a study comprised of 689 patients with GBPs. $60 \%$ of the benign polyps were found as single polyps, whereas $76 \%$ of the malignant polyps were presented as single polyps. In light of these studies, it has been suggested that single polyps should be evaluated together with other contributing risk factors. Bhatt et al. ${ }^{[5]}$ and Kwon et al. ${ }^{[1]}$ reported that sessile polyps have a higher malignancy potential than pedicled polyps. Although Bhatt et al. ${ }^{[5]}$ do not recommended cholecystectomy for sessile polyps, the European Society of Gastrointestinal and Abdominal Radiology (ESGAR) recommends cholecystectomy for all sessile polyps between $6-9 \mathrm{~mm}$ in size. ${ }^{[4]}$ In our study, the polyps were defined considering radiological and pathological examinations. The accurate data on polyp morphology could not be obtained due to the retrospective design of our study.

As with many other cancers, the incidence of gallbladder cancer also increases with advanced age. According to the study conducted by Bhatt et al.,, ${ }^{[5]}$ the probability of malignancy was $20.7 \%$ in patients with a polyp size of $\leq 10$ $\mathrm{mm}$, and the patients over the age of 50 . Moreover, the European Gastrointestinal Endoscopy Association (ESGE) concluded that patients 50 years of age or older and with polyps of 6-9 $\mathrm{mm}$ in size should undergo a cholecystectomy procedure. ${ }^{[4]}$ In our study, only seven $(46.6 \%)$ patients were over the age of 50 and had polyps $6-9 \mathrm{~mm}$ in size without malignancy out of 15 patients who underwent cholecystectomy.

Up to now, there has been a lack of relevant evidence of an increased malignancy risk due to the association between gallstones and polyps. Aldouri et al. ${ }^{[13]}$ conducted a study with 7I43I patients and found that gallstones increase the risk of malignancy. On the contrary, Park et al. found no relationship between gallstones and malignancy in an analysis of 869 patients with GBP. ${ }^{[2]}$ In our study, the association of polyps and gallstones was found in only one patient on histopathological examination, but no malignancy was observed.

Apart from the risk factors, such as age, the number of polyps, polyp morphology, polyp size, and ethnicity, the presence of PSC disease could increase the risk of malignancy in patients with GBPs. ${ }^{[14]}$ In our study, no patients who underwent cholecystectomy were diagnosed with PSC.

The retrospective character and the small sample size of our study could be count as our study limitations. Besides, evaluating the polyp morphology could enhance the malignancy prediction of GBPs in further studies. On the other hand, since the incidence of GBPs differs regarding ethnicity, the results of our study present the characteristic of our population.

\section{CONCLUSION}

The surgery decision could be possible with a comprehensive history taken and a detailed radiological examination performed after a complete clinical evaluation. In patients with risk factors, such as GBP size $\geq 10 \mathrm{~mm}, 5-9 \mathrm{~mm}$ in size and over 50 years of age, single and sessile GBPs, accompanying with PSC, and in symptomatic patients with a polyp size of $\leq 10 \mathrm{~mm}$, a cholecystectomy should be considered due to increased risk of malignancy.

Ethics Committee Approval

The study was approved by the Kartal Dr. Lütfi Kırdar City Hospital Ethics Committee (date: August 26, 2020, no: $2020 / 5$ |4//84/7).

Peer-review

Internally peer-reviewed.

Authorship Contributions

Concept: M.A.; Design: E.M.; Supervision: A.B.; Fundings: M.A.; Materials: M.A.; Data: E.M.; Analysis: E.M.; Literature search: E.M.; Writing: E.M.; Critical revision: A.B.

Conflict of Interest

None declared.

\section{REFERENCES}

1. McCain RS, Diamond A, Jones C, Coleman HG. Current practices 
and future prospects for the management of gallbladder polyps: a topical review. World J Gastroenterol 2018;24:2844-52. [CrossRef]

2. Lin WR, Lin DY, Tai DI, Hsieh SY, Lin CY, Sheen IS, et al. Prevalence of and risk factors for gallbladder polyps detected by ultrasonography among healthy Chinese: analysis of 34669 cases. J Gastroenterol Hepatol 2008;23:965-9. [CrossRef]

3. Andrén-Sandberg A. Diagnosis and management of gallbladder polyps. N Am J Med Sci 2012;4:203-11. [CrossRef]

4. Wiles R, Thoeni RF, Barbu ST, Yogesh KV, Rafaelsen SR, Dewhurst C, et al. Management and follow-up of gallbladder polyps: joint guidelines between the European Society of Gastrointestinal and Abdominal Radiology (ESGAR), European Association for Endoscopic Surgery and other Interventional Techniques (EAES), International Society of Digestive Surgery - European Federation (EFISDS) and European Society of Gastrointestinal Endoscopy (ESGE). Eur Radiol 2017;27:3856-66. [CrossRef]

5. Bhatt NR, Gillis A, Smoothey CO, Awan FN, Ridgway PF. Evidence based management of polyps of the gall bladder: a systematic review of the risk factors of malignancy. Surgeon 2016;14:278-86. [CrossRef]

6. Chapman R, Fevery J, Kalloo A, Nagorney DM, Boberg KM, Shneider B, et al. Diagnosis and management of primary sclerosing cholangitis. Hepatology 2010;51:660-78. [CrossRef]

7. Aldouri AQ, Malik HZ, Waytt J, Khan S, Ranganathan K, Kum- maraganti $\mathrm{S}$, et al. The risk of gallbladder cancer from polyps in a large multiethnic series. Eur J Surg Oncol 2009;35:48-51. [CrossRef]

8. Jones MW, Deppen JG. Gallbladder Polyp. In: StatPearls. Florida: StatPearls Publishing; 2020. Available at: https://www.ncbi.nlm.nih. gov/books/NBK470211/. Accessed Feb 15, 2021.

9. French DG, Allen PD, Ellsmere JC. The diagnostic accuracy of transabdominal ultrasonography needs to be considered when managing gallbladder polyps. Surg Endosc 2013;27:4021-5. [CrossRef]

10. Babu BI, Dennison AR, Garcea G. Management and diagnosis of gallbladder polyps: a systematic review. Langenbecks Arch Surg 2015;400:455-62. [CrossRef]

11. Kwon W, Jang JY, Lee SE, Hwang DW, Kim SW. Clinicopathologic features of polypoid lesions of the gallbladder and risk factors of gallbladder cancer. J Korean Med Sci 2009;24:481-7. [CrossRef]

12. Park JK, Yoon YB, Kim YT, Ryu JK, Yoon WJ, Lee SH, et al. Management strategies for gallbladder polyps: is it possible to predict malignant gallbladder polyps? Gut Liver 2008;2:88-94. [CrossRef]

13. Aldouri AQ, Malik HZ, Waytt J, Khan S, Ranganathan K, Kummaraganti $\mathrm{S}$, et al. The risk of gallbladder cancer from polyps in a large multiethnic series. Eur J Surg Oncol 2009;35:48-51. [CrossRef]

14. European Association for the Study of the Liver. EASL clinical practice guidelines: management of cholestatic liver diseases. J Hepatol 2009;51:237-67. [CrossRef]

\section{Safra Kesesi Poliplerinde Ameliyat Endikasyonlarımız Doğru mu?}

Amaç: Çoğunlukla non-neoplastik lezyonlar olan safra kesesi poliplerinin malignite potansiyeli taşıması, safra kesesi polibi olan hastanın takip ve tedavi kararında önemli bir unsurdur. Bu çalışmada safra kesesi polibi ön tanısı ile ameliyat edilen hastaların ameliyat endikasyonlarının değerlendirilmesi, radyolojik ve patolojik bulgularının karşılaştırılması amaçlanmıştır.

Gereç ve Yöntem: Kliniğimizde Ocak 20I5-Haziran 2020 tarihleri arasında safra kesesi polibi tanısı ile tedavisi yapılan hastaların demografik ve klinik verileri, histopatolojik özellikler, yapılan girişimler ve komplikasyonları geriye dönük olarak değerlendirildi.

Bulgular: Safra kesesi polibi tanısı ile toplam 93 hastaya kolesistektomi yapıldı. Radyolojik görüntülemede 44 (\%47.3) hastada multipl safra kesesi polibi saptandı ve poliplerin ortalama çapı $6 \mathrm{~mm}$ idi. Histopatolojik incelemede 93 hastanın 33'ünde (\%35.5) polip saptandı. Hastaların 29 'unda (\%3।.2) kolesterolozis, 22'sinde (\%23.6) kolelityazis saptandı ve 16 (\% I7.2) hastada anormali saptanmadı. Kolesterolozis ve kolelityazis II (\%I I.8) hastada birlikte görülürken bir hastada kolelityazis ve safra kesesi polibi saptandı.

Sonuç: Klinik muayene ile poliplerin boyutu, görünümü ve sayısı gibi radyolojik bulgular safra kesesi poliplerinin ameliyat endikasyonunda belirleyici rol oynamaktadır. Hastanın risk faktörleri ve klinik bulgular dikkatli değerlendirilerek ameliyat için doğru karar verilmelidir.

Anahtar Sözcükler: Cerrahi; radyolojik bulgu; safra kesesi polibi. 